\title{
Model Pembelajaran Ekspository sebagai Upaya untuk Meningkatkan Prestasi Belajar Kepariwisataan
}

\section{Made Suweta*}

SMAK Negeri 1 Mas, Gianyar, Indonesia

\section{A R T I C L E I N F O}

Article history:

Received 19 August 2020

Received in revised form

30 September 2020

Accepted 10 October 2020

Available online 29

November 2020

\section{Kata Kunci:}

Model Pembelajaran

Ekspository, Prestasi

Belajar

Keywords:

Expository learning model,

learning achievement
A B S T R A K

Penelitian ini dilaksanakan untuk menerapkan model pembelajaran berupa penggunaan Model Ekspository dalam upaya meningkatkan prestasi belajar kepariwisataan siswa kelas. Kelas yang anggotanya berjumlah 37 orang dipilih menjadi subjek penelitian berdasarkan hsil tes awal dengan rata-rata 64,53 menunjukkan angka dibawah $\mathrm{KKm}$ yang ditetapkan sekolah yitu 75. Objek dari penelitian ini adalah prestasi belajar siswa yang masih menjadi kendala utama dalam pembelajaran. Penelitian ini dilaksanakan dalam 2 siklus dengan jadual mulai bulan Juli sampai dengan Oktober 2019. Data yang diperlukan digali dengan menggunakan tes prestasi belajar berupa tes pilihan ganda. Analisa data yang diperoleh meliputi analisa ratarata prestasi belajar dan ketuntasan belajar klasikal. Hasil yang diperoleh salam penelitian ini adalah model pembelajaran Ekspository dapat meningkatkan prestasi belajar kepariwisataan siswa. Ini terbukti dari nilai rata-rata awal 64,53 meningkat menjadi 71,03 pada siklus 1 dan pada siklus 2 menjadi 78,16. Kesimpulan yang diperoleh dari penelitian ini adalah model pembelajaran Ekspository dapat meningkatkan prestasi belajar kepariwisataan siswa Kelas X. Walaupun penelitian ini sudah dapat membuktikan efek utama dari model pembelajaran ekspository, sudah pasti dalam penelitian ini masih ada hal-hal yang belum sempurna dilakukan, oleh karenanya kepada peneliti lain yang berminat meneliti topik yang sama untuk meneliti bagian-bagian yang tidak sempat diteliti.

\section{A B S T R A C T}

This research was conducted to apply a learning model in the form of using the Expository Model in an effort to increase the tourism learning achievement of class students. The class with 37 members was chosen to be research subjects based on the results of the initial test with an average of 64.53 indicating a number below the $\mathrm{KKm}$ set by the school, which is 75 . The object of this study is student achievement which is still a major obstacle in learning. This research was conducted in 2 cycles with a schedule from July to October 2019. The required data was extracted using a learning achievement test in the form of a multiple-choice test. Analysis of the data obtained includes analysis of the average learning achievement and classical learning completeness. The results obtained in this study are that the Expository learning model can improve students' tourism learning achievement. This is evident from the initial average value of 64.53, increasing to 71.03 in cycle 1 and in cycle 2 becoming 78.16. The conclusion obtained from this research is that the Expository learning model can improve the tourism learning achievement of Class $X$ students. Although this research has been able to prove the main effect of the expository learning model, it is certain that in this study there are still things that have not been done perfectly, therefore to other researchers who are interested in researching the same topic to examine the passages that were not researched. 


\section{Pendahuluan}

Paradigma pendidikan Indonesia telah diubah dari pengajaran kepembelajaran. Hal lain yang juga mengalami perubahan adalah dari pembelajaran yang berpusat pada guru menjadi pembelajaran yang berpusat pada siswa (Suparlan, 2017; Nurkhan, 2016). Oleh karenanya, guru-guru diharapkan mampu menyesuaikan diri dengan perubahan tersebut untuk menerapkan di lapangan sesuai harapan. Semua hal tersebut tidak serta merta bisa dilakukan mengingat kondisi daerah yang sangat berbeda. Perubahan sesuai yang diharapkan tentunya tidak sesegera mungkin bisa terjadi dan tidak gampang untuk dilakukan mengingat kelemahan-kelemahan yang ada. Sulitnya perubahan tentu banyak dipengaruhi oleh faktor dari dalam guru itu sendiri seperti; kemauan menyiapkan bahan yang lebih baik, termasuk kemauan guru itu sendiri untuk menciptakan suasana belajar yang nyaman dan menyenangkan dengan menerapkan metode-metode ajar yang telah didapat di bangku kuliah. Selain itu guru juga kurang mampu untuk dapat mengembangkan keterampilan mengajar yang dapat menarik perhatian siswa dan merangsang siswa lebih giat belajar.

Menurut (Abdullah, 2017) dalam proses belajar mengajar pemilihan dan penggunaan metode yang tepat dalam menyajikan suatu materi dapat membantu siswa dalam mengetahui serta memahami segala sesuatu yang disajikan guru, sehingga melalui tes hasil belajar dapat diketahui peningkatan prestasi belajar siswa. Melalui pembelajaran yang tepat, siswa diharapkan mampu memahami dan menguasai materi ajar sehingga dapat berguna dalam kehidupan nyata. Wardani dan Julaeha mempersyaratkan 7 keterampilan yang mesti dikuasai guru dalam melaksanakan pembelajaran, yaitu: 1) keterampilan bertanya, 2) keterampilan memberi penguatan, 3) keterampilan mengadakan variasi, 4) keterampilan menjelaskan, 5) keterampilan membuka dan menutup pelajaran, 6) keterampilan membimbing diskusi, 7) keterampilan mengelola kelas. Keterampilan-keterampilan ini berhubung dengan kemampuan guru untuk menguasai dasar-dasar pengetahuan yang berhubungan dengan persiapan dan pelaksanaan proses pembelajaran yang akan memberikan dukungan terhadap cara berpikir siswa yang kreatif dan imajinatif. Hal inilah yang menunjukkan profesionalisme guru (Modul IDIK 4307: 1-30).

Selain keterampilan mengajar yang mesti dikuasai guru-guru, penggunaan model-model pembelajaran juga merupakan hal yang sangat penting dalam upaya memajukan suatu bidang tertentu. Model sangat berkaitan dengan teori. Model merupakan suatu analog konseptual yang digunakan untuk menyarankan bagaimana meneruskan penelitian empiris sebaiknya tentang suatu masalah. Jadi model merupakan suatu struktur konseptual yang telah berhasil dikembangkan dalam suatu bidang dan sekarang diterapkan, terutama untuk membimbing penelitian dan berpikir dalam bidang lain, biasanya dalam bidang yang belum begitu berkembang Mark 1976 dalam (Ratna, 1989). Menurut (Nasution, 2017) Metode pembelajaran sangat dibutuhkan dalam sekolah, khususnya bagi pembelajaran di dalam kelas. (Trianto, 2010), menyebutkan bahwa model pembelajaran adalah suatu perencanaan atau pola yang digunakan sebagai pedoman dalam merencanakan pembelajaran di kelas atau pembelajaran tutorial. (Pupuh \& Sobry, 2010) berpendapat makin tepat metode yang digunakan oleh guru dalam mengajar, diharapkan makin efektif pula pencapaian tujuan pembelajaran. Menurut (Asyafah, 2019) Model pembelajaran merupakan salah satu komponen penting dalam pembelajaran. Ada beberapa alasan pentingnya pengembangan model pembelajaran, yaitu: a) model pembelajaran yang efektif sangat membantu dalam proses pembelajaran sehingga tujuan pembelajaran lebih mudah tercapai, b) model pembelajaran dapat memberikan informasi yang berguna bagi peserta didik dalam proses pembelajarannya, c) variasi model pembelajaran dapat memberikan gairah belajar peserta didik, menghindari rasa bosan, dan akan berimplikasi pada minat serta motivasi peserta didik dalam mengikuti proses pembelajaran, d) mengembangkan ragam model pembelajaran sangat urgen karena adanya perbedaan karakteristik, kepribadian, kebiasaan-kebiasaan cara belajar para peserta didik, e) kemampuan dosen/guru dalam menggunakan model pembelajaran pun beragam, dan mereka tidak terpaku hanya pada model tertentu, dan f) tuntutan bagi dosen/guru profesional memiliki motivasi dan semangat pembaharuan dalam menjalankan tugas/profesinya.

Dengan penguasaan model pembelajaran, teori-teori pembelajaran, metode, teknik dan lainnya yang dikuasai guru, semestinya nilai siswa tidak akan rendah. Namun kenyataannya nilai rata-rata siswa kelas X AP 3 pada mata pelajaran kepariwisataan menurut hasil penilaian awal baru mencapai rata-rata 64,53 masih sangat rendah jika diukur dari KKM sebesar 75. Penyebabnya lebih dikarenakan keterbatasan kemauan guru untuk menerapkan semua yang dikuasai demi pencapaian hasil maksimal dalam pembelajaran. Sedangkan dari pihak siswa banyak dipengaruhi oleh kebiasaan belajar mereka yang rendah akibat pengaruh luar, kemampuan ekonomi orang tua dan kebiasaan belajar yang belum dibudayakan. Apabila hal ini terus-menerus dibiarkan tentu berakibat tidak baik bagi dunia pendidikan dan bagi bangsa Indonesia. 
Hal-hal di atas merupakan sesuatu yang mendesak untuk dipecahkan menuntut guru lebih kreatif dan inovatif mencari jalan keluar dengan melakukan penelitian-penelitian yang berguna demi meningkatkan kualitas pendidikan di Indonesia. Menurut (Haviluddin, 2010), pembelajaran yang dapat menjadikan peserta didik aktif akan melahirkan kreativitas dalam pembelajaran tersebut. Hal itu akan menjadikan peserta didik lebih menguasai materi yang disampaikan secara optimal. Untuk itu, diperlukan juga pembelajaran yang dapat menjadikan peserta didik aktif sehingga dapat melahirkan kreativitas serta menggali dan mengembangkan potensi yang dimiliki oleh setiap peserta didik. Model pembelajaran ekspositori adalah model pembelajaran yang menekankan kepada proses penyampaian materi secara verbal dari seorang guru kepada sekelompok siswa dengan maksud agar siswa dapat menguasai materi pelajaran secara optimal. Roy Killen menamakan model ekspositori ini dengan istilah model pembelajaran langsung (dirrect intruction), karena dalam model ini materi pelajaran disampaikan langsung oleh guru. (Sudjana, 2002) menyatakan bahwa kegiatan pembelajaran yang berpusat pada guru menekankan pentingnya aktivitas guru dalam proses belajar mengajar. Menurut (Atriyanto \& Sulistiyo, 2014) Startegi ekspositori adalah strategi pembelajaran yang memadukan metode ceramah, tanya jawab, dan peragaan demonstrasi. Dengan dipadukannya berbagai metode tersebut dalam kegiatan pembelajaran diharapkan siswa dapat memahami materi ajar tersebut. Menurut (Rizal, 2016) Metode Ekspositori adalah metode pembelajaran yang menekankan pada proses penyampaian materi secara verbal dari seorang guru kepada sekelompok siswa dengan maksud agar siswa dapat menguasai materi pelajaran secara optimal.

(Sadia, 1996) mendefisikan model belajar konvensional sebagai rangkaian kegiatan belajar yang dimulai dengan orientasi dan penyajian informasi yang berkaitan dengan konsep yang akan dipelajari, dilanjutkan dengan pemberian ilustrasi atau contoh soal oleh guru, diskusi tanya-jawab sampai akhirnya guru merasa bahwa apa yang telah diajarkannya dapat dimengerti oleh siswa. Ausubel (Romiszowski, 1990) menyatakan model pembelajaran konvensional atau ekspositori didasarkan pada proses meaningful reception learning. Pendekatan ini cenderung menekankan penyampaian informasi yang bersumber dari buku teks, referensi atau pengalaman pribadi dengan menggunakan teknik ceramah, demonstrasi, diskusi dan laporan studi. Dengan demikian pengetahuan yang akan dipelajari siswa harus disajikan dan guru perlu memberikan berbagai definisi dari konsep yang akan diterima siswa.

Dalam pembelajaran ekspositori guru cenderung memegang kontrol proses pembelajaran yang aktif, sementara siswa relalif pasif menerima dan mengikuti apa yang disajikan oleh guru. Pembelajaran ekspositori merupakan pembelajaran yang lebih berpusat pada guru (teacher centered), guru menjadi sumber dan pemberi informasi utama dengan maksud agar peserta didik dapat menguasai materi pembelajaran secara optimal (Hasbiyalloh et al., 2017; Watoni, 2014). Meskipun dalam pembelajaran ekspositori digunakan metode selain ceramah dengan menggunakan berbagai media namun penekanannya tetap lebih pada proses penerimaan pengetahuan. Menurut Sanjaya (dalam Hasbiyalloh et al., 2017)Keunggulan model pembelajaran ini adalah (a) dengan model pembelajaran ekspositori guru bisa mengontrol urutan dan keluasan materi pembelajaran, dengan demikian guru dapat mengetahui sampai sejauh mana peserta didik menguasai bahan pelajaran yang disampaikan, (b) model pembelajaran ekspositori dianggap sangat efektif apabila meteri pembelajaran yang harus dikuasai peserta didik cukup luas, sementara itu waktu yang dimiliki untuk belajar terbatas, (c) peserta didik dapat mendengar melalui penuturan tentang suatu materi pelajaran, juga sekaligus peserta didik bisa melihat atau mengobservasi (melalui pelaksanaan demonstrasi), dan (d) model pembelajaran ini bisa digunakan untuk jumlah peserta didik dan ukuran kelas yang besar. Pada pembelajaran ekspositori siswa diharapkan telah siap mental menerima apa yang diberikan guru atau mengikuti apa kehendak guru. Guru biasanya yang mendemonstrasikan sesuatu untuk menjelaskan konsep, prinsip, hukum atau teori-teori tertentu.

Namun model pembelajaran yang berpusat pada guru ini memiliki keunggulan: 1) bahan belajar dapat disampaikan secara tuntas, 2) dapat diikuti oleh siswa dalam jumlah besar, 3) pembelajaran dapat dilaksanakan sesuai dengan alokasi waktu yang ditetapkan, 4) target materi relatif mudah dicapai. Sedangkan kelemahannya yang mungkin terjadi adalah:1) membosankan, 2) keberhasilan perubahan sikap dan prilaku peserta didik relatif sulit diukur, 3) kualitas pencapaian tujuan belajar yang telah ditetapkan adalah relatif rendah karena pendidik sering hanya mengejar target waktu untuk menghabiskan target materi pembelajaran, dan pembelajaran kebanyakan menggunakan ceramah dan jawab (Sudjana, 2005). Jadi Kelebihan dari pendekatan ini adalah mudah dilakukan karena tanpa memerlukan suatu rangkaian khusus pembelajaran dapat diterapkan pada materi yang mudah diakses siswa yang lebih bersifat hafalan. Sementara kelemahannya adalah: 1) kurang memberikan kesempatan bagi berkembangnya kemampuan eksplorasi, kreativitas, kemandirian dan sikap kritis siswa. 2) cenderung menimbulkan sikap pasif pada siswa karena terbiasa menerima. 3) kegiatan cenderung bersifat mekanistis. Jadi model pembelajaran ekspositori tidak dilandasi oleh paham konstruktivisme (Sanjaya,2006). 
Model ekspositori dalam kajian ini adalah menekankan pada pembelajaran biasa dipergunakan oleh guru dalam praktek pembelajaran secara aktual di lapangan. Sintak pembelajaran dengan model ekspositori adalah; 1) pada tahap pendahuluan guru menyampaikan pokok-pokok materi yang akan dibahas dan tujuan pembelajaran yang ingin dicapai, 2) pada tahap inti guru menyampaikan materi dengan ceramah, tanyajawab, dilanjutkan demonstrasi atau eksperimen untuk memperjelas konsep diakhiri dengan penyampaian ringkasan atau latihan-latihan soal, 3) pada tahap penutup guru memberikanevaluasi maupun tugas-tugas untuk dikerj akan di rumah.

Secara sederhana proses pembelajaran dengan model ekspositori digambarkansebagai berikut:

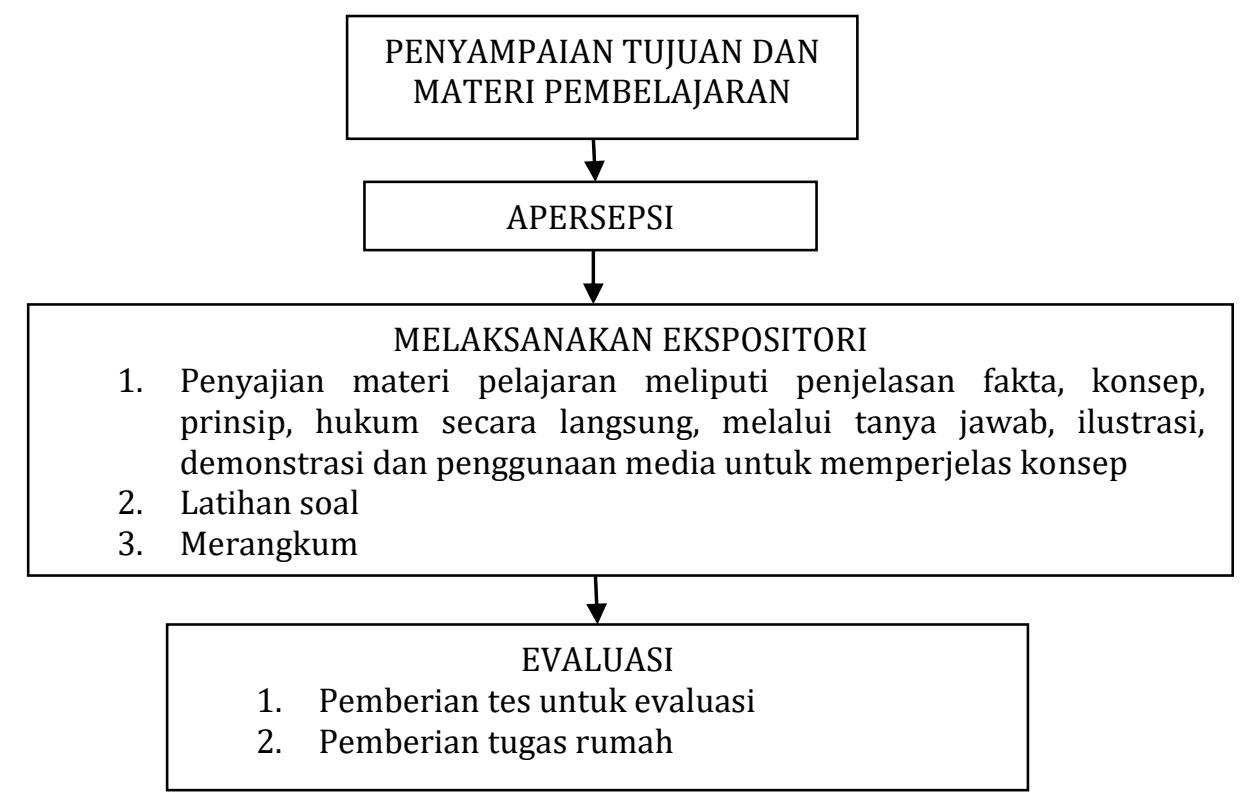

Gambar 1. Prosedur Penerapan Pembelajaran Ekspositori

\section{Metode}

Penelitian ini merupaan penelitian tindakan kelas dengan menggunakan rancangan penelitian Kemmis and Taggart menggunakan langkah-langkah suatu siklus yang meliputi perencanaan, tindakan, observasi, dan refleksi. Penelitian dlakukan di SMK Negeri 1 Mas, Ubud pada kelas X AP 3 tahun pelajaran 2019/2020 yang berjumlah 37 orang. Sebelum diberikan pelajaran, siswa pada kelas yang dipakai sebagai tempat penelitian terlebih dahulu diberikan tes awal untuk mengetahui prestasi belajar kepariwisataan. Hasil tes awal dianalisis untuk mendapatkan nilai rata-rata prestasi belajar kepariwisataan siswa. Data yang dikumpulkan dalam penelitian ini adalah prestasi belajar kepariwisataan dengan model pembelajaran eksposotory. Hipotesis tindakan yang dapat dirumuskan dalam penelitian ini adalah terjadi peningkatan prestasi belajar kepariwisataan siswa kelas X AP 3 SMK Negeri 1 Mas pada semester 1 tahun pelajaran 2019/2020 setelah digunakan model pembelajaran ekspository pada pembelajaran kepariwisataan secara konsisten.

\section{Hasil dan Pembahasan}

Terjadi peningkatan sebanyak 10,07\% dari rata-rata awal prestasi belajar kepariwisataan siswa dari 64,53 menjadi 71,03 pada siklus 1 , dan sebanyak 10,04\% prosentase peningkatan prestasi belajar kepariwisataan siswa dari rata-rata 71,03 pada siklus 1 menjadi 78,16 pada siklus 2 . Fakta ini membuktikan bahwa model pembelajaran ekspository dalam pelajaran kepariwisataan dapat secara efektif meningkatkan prestasi belajar siswa.

Hal ini tidak terlapas dari model pembelajaran yang diberikan, dimana model pembalajaran ini membuat siswa lemih aktif dan tentunya hal ini secara langsung akan mempangaruhi hasil belajar. Dengan siswa aktif siswa menemukan dan membangun pengetahunnya sendiri. Menurut (Haviluddin, 2010), pembelajaran yang dapat menjadikan peserta didik aktif akan melahirkan kreativitas dalam pembelajaran tersebut. Hal itu akan menjadikan peserta didik lebih menguasai materi yang disampaikan secara optimal. Untuk itu, diperlukan juga pembelajaran yang dapat menjadikan peserta didik aktif sehingga dapat melahirkan kreativitas serta menggali dan mengembangkan potensi yang dimiliki oleh 
setiap peserta didik. Model pembelajaran ekspositori adalah model pembelajaran yang menekankan kepada proses penyampaian materi secara verbal dari seorang guru kepada sekelompok siswa dengan maksud agar siswa dapat menguasai materi pelajaran secara optimal. Roy Killen menamakan model ekspositori ini dengan istilah model pembelajaran langsung (dirrect intruction), karena dalam model ini materi pelajaran disampaikan langsung oleh guru. (Sudjana, 2002) menyatakan bahwa kegiatan pembelajaran yang berpusat pada guru menekankan pentingnya aktivitas guru dalam proses belajar mengajar. Menurut (Atriyanto \& Sulistiyo, 2014) Startegi ekspositori adalah strategi pembelajaran yang memadukan metode ceramah, tanya jawab, dan peragaan demonstrasi. Dengan dipadukannya berbagai metode tersebut dalam kegiatan pembelajaran diharapkan siswa dapat memahami materi ajar tersebut. Menurut Rizal (2016) Metode Ekspositori adalah metode pembelajaran yang menekankan pada proses penyampaian materi secara verbal dari seorang guru kepada sekelompok siswa dengan maksud agar siswa dapat menguasai materi pelajaran secara optimal.

Penelitian yang dilakukan oleh (Sukardi, 2018) menyatakan bahwa (Hasbiyalloh et al., 2017) menyatakan bahwa model pembelajaran Expository dapat meningkatkan prestasi belajar. Kemudian penelitian yang dilakukan oleh (Hasbiyalloh et al., 2017) menyatakan bahwa terdapat pengaruh model pembelajaran ekspositori dengan scaffolding dan advance organizer terhadap hasil belajar fisika siswa.

Model pembelajaran yang berpusat pada guru ini memiliki keunggulan: 1) bahan belajar dapat disampaikan secara tuntas, 2) dapat diikuti oleh siswa dalam jumlah besar, 3) pembelajaran dapat dilaksanakan sesuai dengan alokasi waktu yang ditetapkan, 4) target materi relatif mudah dicapai. Sedangkan kelemahannya yang mungkin terjadi adalah: b1) membosankan, 2) keberhasilan perubahan sikap dan prilaku peserta didik relatif sulit diukur, 3) kualitas pencapaian tujuan belajar yang telah ditetapkan adalah relatif rendah karena pendidik sering hanya mengejar target waktu untuk menghabiskan target materi pembelajaran, dan pembelajaran kebanyakan menggunakan ceramah dan jawab (Sudjana, 2005). Jadi Kelebihan dari pendekatan ini adalah mudah dilakukan karena tanpa memerlukan suatu rangkaian khusus pembelajaran dapat diterapkan pada materi yang mudah diakses siswa yang lebih bersifat hafalan. Sementara kelemahannya adalah: 1) kurang memberikan kesempatan bagi berkembangnya kemampuan eksplorasi, kreativitas, kemandirian dan sikap kritis siswa. 2) cenderung menimbulkan sikap pasif pada siswa karena terbiasa menerima. 3) kegiatan cenderung bersifat mekanistis. Jadi model pembelajaran ekspositori tidak dilandasi oleh paham konstruktivisme (Sanjaya, 2006).

\section{Simpulan dan Saran}

Adanya hasil analisis permasalahan pada kelas ini berupa rendahnya prestasi belajar kepariwisataan siswa ada pada faktor faktor seperti model pembelajaran yang digunakan guru tidak semuanya efektif bagi siswa. Sehingga, perlu disesuaikan dengan karakteristik siswa untuk memudahkan siswa memahami materi pembelajaran. Untuk mengatasi rendahnya prestasi belajar kepariwisataan siswa di SMK Negeri 1 Mas, digunakan model pembelajaran Ekspository.

Berdasarkan pada rendahnya prestasi belajar kepariwisataan siswa yang disampaikan pada latar belakang masalah, penggunaan model pembelajaran Ekspository pat menyelesaikan tujuan penelitin ini untuk meningkatkan prestasi belajar siswa kelas X AP 3 SMK Negeri 1 Mas pada semester 1 tahun pelajaran 2019/2020. Seberapa besar peningkatan yang dicapai sudah dipaparkan dengan jelas pada akhir analisi dari hasil penelitian pada Bab IV. a) Nlai rata-rata awal 64.53 meningkat menjadi 71,03 pada siklus 1 dan pada siklus 2 naik menjadi 78,16; b) Dari data awal siswa yang tuntas adalah $6(16,22 \%)$ siswa, sedangkan pada siklus 1 menjadi cukup banyak yaitu $12(32,43 \%)$ siswa, dan pada siklus 2 menjadi $32(8649 \%)$ siswa.

Dari semua data pendukung, pembuktian pencapaian tujuan pembelajaran dapat disampaikan bahwa model pembelajaran Ekspository dapat member jawaban yang diharapkan sesuai tujuan penelitian ini. Semua ini dapat dicapai adalah akibat kesiapan dan kerja keras peneliti dari sejak pembuatan proposal, review hal-hal yang belum bagus bersama teman-teman guru, penyusunan instrument penelitian, penggunaan sarana triangulasi data sampai pada pelaksanaan penelitian yang maksimal.

Berdasarkan pada beberapa temuan pada penelitian ini, dan dengan mempertimbangkan implikasinya, maka dapat dirumuskan saran sebagai berikut; 1) Kepada guru kepariwisataan, diharapkan dalam melaksanakan proses pembelajaran menggunakan model pembelajaran Ekspository sebagai pilihan dari beberapa model yang ada mengingat model ini telah terbukti dapat meningkatkan prestasi belajar siswa serta dapat meningkatkan kepercayaan diri siswa dalam mengikuti pembelajaran; 2) Walaupun penelitian inisudah dapat membuktikan efek utama dari model pembelajaran Ekspository dalam meningkatka prestasi belajar kepariwisataan, sudah pasti dalam peelitian ini masih ada hal-hal yang belum sempurna dilakukan, oleh karenanya kepada peneliti lain yang berminat meneliti topic yang 
sama untuk meneliti bagian-bagian yang belum sempat diteliti; 3) Kepada sekolah, disarankan untuk merekomendasikan model pembelajaran pada bidang studi lainnya, sehingga prestasi belajar siswa meningkat tidak hanya di bidang mata pelajaran kepariwisataan.

\section{Daftar Rujukan}

Abdullah. 2017. Pendekatan dan Model Pembelajaran yang Mengaktifkan Siswa. Edureligia, Vol. 01 No. 01 Hal. 45-62. Tersedia Pada: https://ejournal.unuja.ac.id/index.php/edureligia/article/view/45.

Asyafah. Abas, 2019. Menimbang Model Pembelajaran (Kajian Teoretis-Kritis atas Model Pembelajaran dalam Pendidikan Islam). TARBAWY: Indonesian Journal of Islamic Education - Vol. 6 No. 1 Hal. 19-32. Tersedia Pada: http://ejournal.upi.edu/index.php/tarbawy/index.

Atriyanto, Bayu, Edy Sulistiyo. 2014. "Pengaruh Strategi Pembelajaran Ekspositori terhadap Hasil Belajar Siswa pada Mata Diklat Memperbaiki Compact Cassete Recorder Kelas XI TAV di SMA Negeri 2 Surabaya". Jurnal Pendidikan Teknik Elektro, Volume 03, Nomor 02, Tahun 2014, Hal. 09 - 13. Tersedia Pada: https://jurnalmahasiswa.unesa.ac.id/index.php/jurnal-pendidikan-teknikelektro/article/view/7484.

Dahar, Ratna Wilis. 1989. Teori-Teori Belajar. Jakarta: Penerbit Erlangga..

Haviluddin. 2010. Active Learning Berbasis Teknologi Informasi ICT. Jurnal Informatika Mulawarman, 5(2): 28-31. Tersedia di http://informatikamulawarman.files.wordpr ess.com/2010/09/04jurnal-informatika-

Nasution, Mardiah Kalsum. 2017. Penggunaan Metode Pembelajaran dalam Peningkatan Hasil Belajar Siswa. STUDIA DIDAKTIKA: Jurnal Ilmiah Bidang Pendidikan Vol. 11, No. 1, Hal. 9-16. Tersedia Pada: http://jurnal.uinbanten.ac.id/index.php/studiadidaktika/article/view/515.

Pupuh Faturrohman \& Sobry M. S. (2010). Strategi Belajar Mengajar melalui Penanaman Konsep Umum \& Konsep Islami, Bandung: Refika Aditama.

Rizal M., Muh, Thamrin Tayeb, Nurkholisah Latuconsina. 2016. Efektivitas Penerapan Metode Ekspositori Berbasis Kuis terhadap Hasil Belajar Matematika Siswa Kelas VIII MTsN MA ' R A N G Kabupaten Pangkep. MaPan : Jurnal Matematika dan Pembelajaran, Vol. 2 No. 2 Hal. 172-185. Tersedia Pada: http://journal.uin-alauddin.ac.id/index.php/Mapan/article/view/3161.

Sadia. 2003a. Strategi Pembelajaran Berorientasi Kurikulum Berbasis Kompetensi. Makalah Disajikan pada Seminar Peningkatan Profesionalisme Guru-Guru SD Negeri 3 Singaraja dalam Menyongsong KBK 2003 Tanggal 26 Januari 2003.

Sudjana, Nana. 2002. Penilaian Hasil Proses Belajar Mengajar. Bandung: PT Remaja Rosdakarya.

Trianto. (2010). Mendesain Model Pembelajaran Inovatif- Progesif. Jakarta: Kencana.

Wina Sanjaya. 2006. Strategi Pembelajaran Berorientasi Standar Proses Pendidikan. Kencana Prenada Media: Jakarta.

Hasbiyalloh, A. S., Harjono, A., \& Verawati, N. N. S. P. (2017). Pengaruh Model Pembelajaran Ekspositori Berbantuan Scaffolding Dan Advance Organizer Terhadap Hasil Belajar Fisika Peserta Didik Kelas X. Jurnal Pendidikan Fisika Dan Teknologi, 3(2), 173. https://doi.org/10.29303/jpft.v3i2.397

Nurkhan, N. (2016). Penilaian Kurikulum 2013 Melalui Pendampingan Bagi Guru Sekolah. Jurnal Refleksi Edukatika, 7(1). https://doi.org/https://doi.org/10.24176/re.v7i1.912

Sukardi, N. M. (2018). Peningkatan Prestasi Belajar Agama Hindu SMP Melalui Model Pembelajaran Ekspositori. Journal of Education Action Research, 2(3), 276. https://doi.org/10.23887/jear.v2i3.16265

Suparlan, S. (2017). Implementasi Pendekatan Saintifik Kurikulum 2013 pada Pembelajaran IPA di SD/MI Kelas IV. Fondatia, 1(2). https://doi.org/https://doi.org/10.36088/fondatia.v1i2.104

Watoni, M. S. (2014). Studi Komprasi Penerpan Inquiry Dengan Pendekatan Ekspositori Terhadap Prestasi Belajar Siswa Kelas X MA Palapa Nusantara. Palapa, 2(2). https://doi.org/https://doi.org/10.36088/palapa.v2i2.746 